\title{
History and environment of Barrow Island
}

\author{
Dorian Moro and Russell Lagdon
}

\author{
Chevron Australia Pty Ltd, 250 St Georges Terrace, Perth, Western Australia 6000, Australia. \\ Email:dmmv@chevron.com
}

\begin{abstract}
Barrow Island represents a unique island ecosystem off north-western Australia. It has ecological affinities to the Cape Range region of the Australian mainland, and it also supports an oil and gas resource industry. The island hosts a long-unburnt vegetation complex, and a diverse community of vertebrate and invertebrate fauna occupy the disturbed and undisturbed habitats of the island. In the absence of non-indigenous predators or herbivores, without extensive land clearing, and with an instituted level of island quarantine, these environmental values have persisted to make Barrow Island an important environmental asset for Australia, and an example where island ecology functions in the presence of resource extraction. To date, almost 2,800 species of terrestrial and subterranean species have been consistently recorded from Barrow Island. These include 378 native plant species, 13 mammal species (including two species of bats), at least 119 species of terrestrial and migratory birds, 43 species of terrestrial reptiles, one species of frog, three subterranean vertebrates, at least 34 species of subterranean invertebrates, and the most speciose of all, over 2,200 terrestrial invertebrates.
\end{abstract}

KEYWORDS: Barrow Island, Chevron, exploration of Australia, industry, island, invertebrate

\section{INTRODUCTION}

Barrow is old, harsh and rugged but in its own way is still wonderful and beautiful (Horsburgh 2008).

The Pilbara Region lies in the tropical waters of Australia's north-west shelf. This region is scattered with numerous small islands, the largest of which is Barrow Island $\left(20^{\circ} 45^{\prime} \mathrm{S}, 115^{\circ} 25^{\prime} \mathrm{E}\right)$. At $25 \mathrm{~km}$ in length, $10 \mathrm{~km}$ in width, approximately 23,400 hectares above the high-tide mark, and some $56 \mathrm{~km}$ off the mainland, Barrow Island is Western Australia's second largest continental island (Figure 1).

In 1910, Barrow Island was listed as a Class A nature reserve for the purpose of conservation of flora and fauna, with reserve status extending to the low water mark. Barrow Island is vested in the Conservation Commission of Western Australia and managed by the Western Australian Department of Environment and Conservation for conservation. A management plan for the marine conservation reserves surrounding Barrow Island (including Bandicoot Bay Conservation Area, Barrow Island Marine Park) and the Montebello Islands was completed for the 2007-2017 period (DEC 2006), and a management plan for the terrestrial reserve is underway.

However, Barrow Island is not in an undisturbed state as it also supports an operating oilfield, and has done so since the 1960s. More recently it supports the construction of the Gorgon Liquefied Natural Gas Development and its future operations (Chevron Australia 2005, 2006). Understanding the human and natural history of Barrow Island, together with present day disturbances, helps to place its ecosystems into context in terms of its remoteness, its ecological affinities with the mainland and its resilience to accommodate environmental extremes. With interest in the Gorgon Gas Development approvals process has included the accrual of a significant amount of ecological knowledge to support impact assessment and environmental (including quarantine) monitoring programs. An important part of this knowledge has been the expansion of our understanding of the invertebrate assemblages that occur on this remote island.

\section{HUMAN HISTORY AND EXPLORATION}

Indigenous people inhabited the area of what is now Barrow Island well before rising sea levels separated it from the mainland around 8,000 years ago. Since then, there has been limited evidence of continued occupation on Barrow Island, although evidence exists of their occupation on the nearby Montebello land mass (Veth 1994). More recently, indigenous occupation on the island has been related to the early pearling interests in the area. 


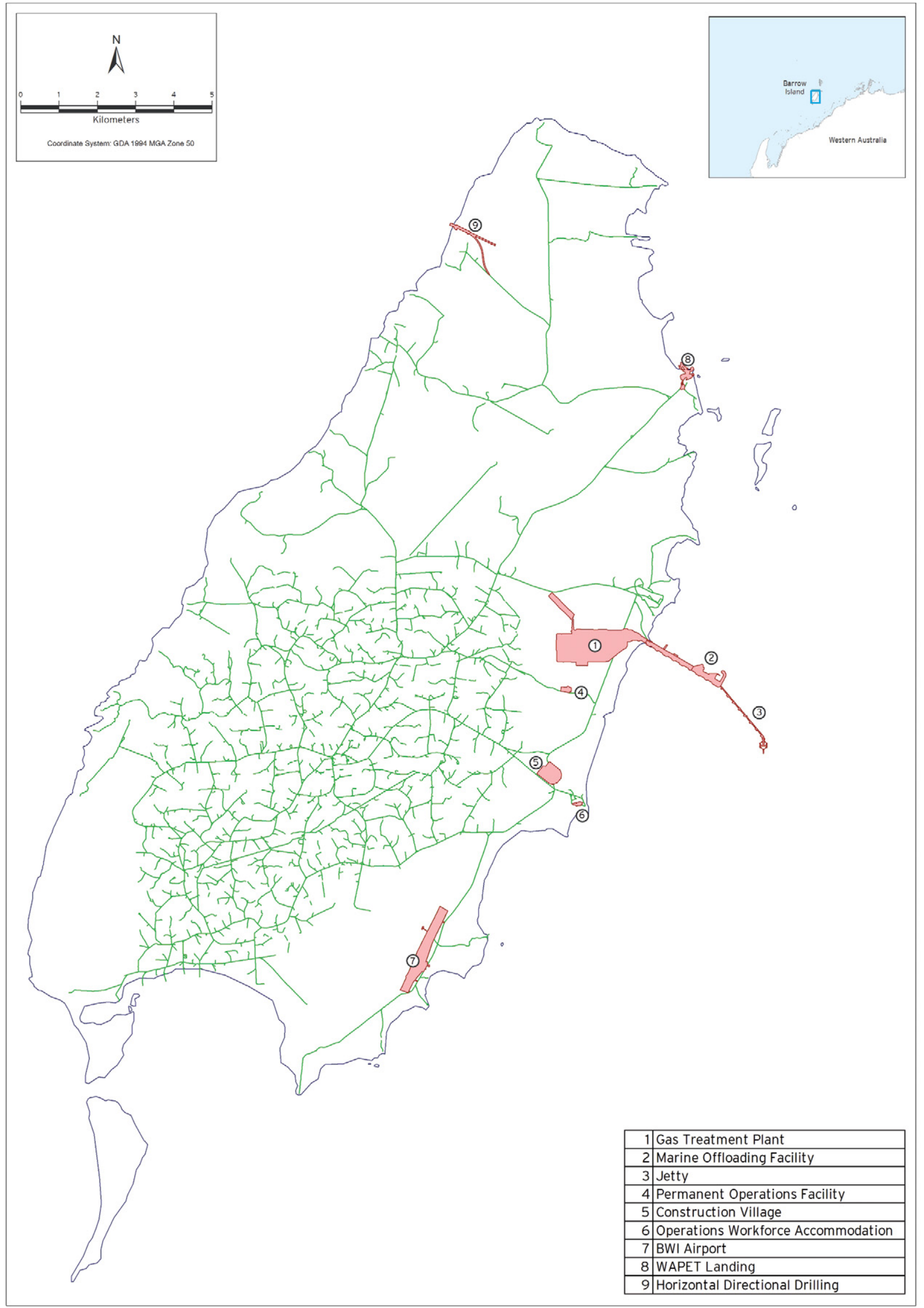

FIGURE $1 \quad$ Location map of Barrow Island Nature Reserve, Western Australia. Gorgon Project infrastructure is labelled. Road network appears as lines across the island. 
The following synopsis briefly describes the cultural activities reported from historical sources that relate to Barrow Island; citations and additional sources can be found in Hook et al. (2005).

The wreck of the British East India Company ship Tryal just north of Barrow Island in 1622 is Western Australia's first recorded shipwreck. The first European record of Barrow Island was found in a Dutch East India Company map in 1628. The French navigator Baudin thought it was part of the mainland as he sailed past in 1803, and named several prominent landmarks on the island such as Cape Poivre, Flacourt Bay, and Cape Dupuy.

In 1818, Lieutenant Phillip Parker King, who surveyed the North West Australian coast, named the island after John Barrow, a secretary of the British Admiralty. The mid to late 1800s saw activity in the north-west by whaling vessels, and the establishment of pearl shell industries. By 1840 observations of flora and fauna were being recorded and specimens collected by explorers such as Stokes (1846) and Jarman (1864).

After the 1860s, several pearling camps were located on Barrow Island, particularly in the sheltered waters of the south of the island where Aboriginal pearlers were left marooned for weeks before their vessel returned: remains of camps confirm their presence there. Barrow Island was additionally used as a quarantine station for Aboriginal people with measles (1884), believed to be those involved in the pearling industry. The island also supported a Lock Hospital presumably for venereal diseases (1908), and barracoons for Aboriginal people involved in the pearling industry (late 1800s). In 1871, the first lease on Barrow Island was granted for turtle fishing. Subsequent leases were applied for "tortoise" (turtle) shell and oil, fishing and pastoral purposes, but most leases were forfeited. There was no significant effort to settle the island because of the lack of surface water and the distance of Barrow Island from the mainland.

In 1900, the naturalist J.T. Tunney spent time on the island collecting birds and mammals. As a result of these collections and the interest they generated, Barrow Island was listed in Western Australia as a public reserve for flora and fauna in 1908, a classification upgraded in 1910 to a Class A Nature Reserve which meant that its status could not be changed without approval from both Houses of State Parliament. Visits to Barrow Island in later years mainly related to scientific investigations of its fauna and flora. However, these visits ceased in 1952 with the British atomic tests on the nearby Montebello Islands. Limited access to the island resumed 10 years later. From 1964, the island was visited by the naturalist Dr W.H (Harry) Butler, who recorded wildlife and collected specimens for the Western Australian Museum (Butler, unpubl. data).
Petroleum interest in Barrow Island dates back to June 1947, when the first exploration permit was issued to the Australian Motorists Petrol Company (AMPOL). The permit was re-issued to West Australian Petroleum in 1952 and preliminary geological reconnaissance started in 1954 (Smith 1962). Oil was discovered on Barrow Island in 1964. The island was managed by West Australian Petroleum up to 2000, and then by Chevron Australia. Since 1964, more than 318 million barrels of oil have been produced. Both companies committed to protect the conservation values of this important nature reserve by installing an active quarantine program for cargo that was shipped to the island. In parallel, Dr Butler played an instrumental role in developing environmental codes of conduct and their enforcement amongst the workforce and operators to support the company to balance its production goals whilst maintaining the conservation values of the reserve.

In February 2003, Chevron Australia proposed to develop the Gorgon gas field, $80 \mathrm{~km}$ off the west coast of Barrow Island. With government in-principle approval to proceed with a gas processing plant and shipping facility on the island (Government of Western Australia 2008, 2009; Commonwealth Government of Australia 2007, 2009), plans commenced to seek the necessary environmental approvals. One of the early actions taken was the establishment of an independent Quarantine Expert Panel to provide advice to Chevron Australia on international best practice for the necessary upgrade of quarantine measures required to manage an increased cargo to construct the gas plant, while maintaining protection of the biodiversity of Barrow Island. Early recommendations of the Panel were to collect baseline data on the biodiversity of Barrow Island, particularly its invertebrate communities which were under-studied.

\section{NATURAL ENVIRONMENT}

Barrow Island Nature Reserve is important as a refuge for wildlife. While all species and subspecies are native to Barrow Island, some are listed as endemic, vulnerable and/or threatened and have reduced populations on mainland Australia. While the persistence of wildlife (specifically the mammal species) on Barrow Island can be attributed to its isolation from mainland Australia following human colonisation, this persistence can also be explained by their resilience to evolve within an environment that experiences extreme fluctuations in climate and in particular, rainfall. The protection of this reserve is now due to its statutory status and the decades of environmental management by Chevron Australia and its predecessor; together these have played an important role in protecting 
the biota from introduced vertebrate species common elsewhere.

\section{GEOLOGY AND LANDFORMS}

Over geological time, the land mass that became Barrow Island experienced several sea level changes connecting and separating the flora and fauna from the nearby Australian mainland. More recently, 8,000 to 10,000 years ago, rising sea levels once again separated Barrow Island from the mainland. Sea levels continued to rise above existing levels some 6,000 years ago creating further isolation of the island landmass and dividing it into two smaller islands (Playford 1997). Repeated separation and connectedness continued between 5,000 to 4,000 years ago until sea levels dropped to present levels some 2,000 years ago, creating the land mass of Barrow Island today. These sea level rises and falls have been important for developing an environment of creeklines, beaches, and cliffs, and contributing to a diversity of habitats and biota found across the island.

Barrow Island lies within the North Coast IBRA region (Thackway and Cresswell 1995; Environment Australia 2000) and has biogeographical and ecological affinities with the neighbouring Pilbara bioregion and the Cape Range. The island is composed almost entirely of limestone outcrops and deposits overlain by sands and gravels and capped by a travertine stone.

Broad geomorphic units identified across the island include limestone uplands, near coastal lowlands, coastal fringe, and intertidal platform. Landforms on Barrow Island are predominantly developed by coastal processes that are dominated by the effects of wind and water. Five landscape units have been identified (Table 1). The onshore terrain ranges from undulating sand dunes and plains on the western side, including steep formed valleys, escarpments and exposed limestone ridges, claypans, to gently undulating rocky terrain leading to dune systems and mangroves on the eastern side. Inland the area is flat to undulating and gradually slopes upward from the coastline.

\section{CLIMATE}

Barrow Island is characterised by an arid and sub-tropical climate. The summer season (October to March) experiences high temperatures, high humidity, and predominantly south-west winds, largely controlled by the seasonal movements of high pressure anti-cyclonic weather systems (Worley 2003). Mean daily maximum temperatures reach $34^{\circ} \mathrm{C}$, with mean daily minimum temperatures averaging $20^{\circ} \mathrm{C}$. During the winter season, mean daily maximum temperatures reach $26^{\circ} \mathrm{C}$, with mean daily minimum temperatures of $17^{\circ} \mathrm{C}$.
Rainfall on Barrow Island is seasonal, and is dependent on rain-bearing low pressure systems, thunderstorm activity and the passage of tropical cyclones (most prevalent from November to April). Wet years typically receive a large portion of rainfall from tropical cyclones and winter rains. The historic annual average rainfall for the area is $320 \mathrm{~mm}$. Dew, however, is common and provides an important source of fresh water. During the early winter months (June-July) rainfall is received from frontal systems passing to the south. These events can result in up to $75 \mathrm{~mm}$ of rain which accounts for approximately 35\% of annual rainfall (Chevron Australia 2005). In summer, cyclonic events range from storms of $300 \mathrm{~mm}$ to milder $30 \mathrm{~mm}$ events.

\section{TERRESTRIAL ECOLOGY}

Ecologically, there are six broad terrestrial values (flora and vegetation, avifauna, mammals, reptiles and amphibians, invertebrates, subterranean fauna) and eight broad marine values (reefs, conservation areas, macrophytes, mammals, avifauna, reptiles, fish, invertebrates) that define Barrow Island. Of importance to this island ecosystem is the absence of recent fire. While small-scale fires have occurred over the years, the vegetation has not had a large-scale burn since the late 1950s such that the majority of vegetation remains aged ( $>50$ years unburnt; Smith 1962). Also absent from Barrow Island are threatening species and processes common across mainland Australia: namely introduced predators (fox, cat) and competitors (rabbits, goats), widespread land clearing for agriculture, honey bees and exotic rats and mice. The resilience of native species that have evolved in this dynamic insular environment is linked to the climatic extremes they have evolved within, an important factor assisting their persistence on the island.

Almost 2,800 species of terrestrial and subterranean plants and animals have been consistently recorded on Barrow Island (Moro and MacAulay 2010a). These include 378 native plant species (approximately $21 \%$ of the flora records documented for the Pilbara region), 13 mammal species (including two species of bats), at least 119 species of terrestrial and migratory birds, 43 species of terrestrial reptiles, one species of frog, three subterranean vertebrates (an eel, a fish and a snake), over 2,200 terrestrial invertebrates, and at least 34 species of subterranean invertebrates. Twenty-four terrestrial species and subspecies are not known to occur elsewhere, and another five terrestrial species have restricted distributions elsewhere.

The waters surrounding Barrow Island are protected within marine conservation reserves, including the Barrow Island Marine Park with an estimated 9,000 species. The marine intertidal 
TABLE $1 \quad$ Landscape Units of Barrow Island (Chevron Australia 2005).

\section{Landscape Unit}

West Coastal Complex

\section{East Coastal Complex}

Valley Slopes and Escarpments

Limestone Ridges

Creek or Seasonal Drainage lines

\section{Description}

The west coast of Barrow Island is exposed to direct wind and wave action from the Indian Ocean. The coastline topography varies from rocky weathered sheer cliffs to less steep, traversable inclines.

Typically narrow sandy beaches occur between weathered rocky headlands. Vegetation types along the west coast are dominated by Spinifex longifolius. This coastline is a significant feature of Barrow Island.

The eastern coastline is protected with a slight land gradient to the ocean. This coastline is characterised by vegetated sand dunes and expansive tidal flats.

Vegetation types along the east coast are dominated by Triodia angusta and Acacia coriacea.

The western half of Barrow Island is characterised by steep formed valleys, escarpments and exposed limestone ridges.

Typical vegetation on valley slopes and escarpments is described as open, low shrubland dominated by Triodia wiseana. Mixed emergent lower growing shrub species such as Acacia bivenosa, Petalostylis labicheoides and Pentalepis trichodesmoides occur on the southern escarpments.

This landscape unit occurs generally throughout the central upland plateaus of the island. The terrain ranges from steeper slopes in the west to flatter more gentle undulations as the ridges continue east.

Typical vegetation on the limestone ridges includes hummock grassland of Triodia wiseana with low mixed shrubs including Acacia gregorii and Melaleuca cardiophylla.

This landscape unit occurs in the broad valleys and flats of limestone ridges and is located adjacent to the coastal fringes. This landscape has deeper alluvial soil structure and denser and taller vegetation.

The vegetation in this unit type is described as mixed hummock grassland of Triodia angusta with pockets of dense shrubs along major creek lines. 
environment includes a diverse community of corals, seagrass, macroalgae, and benthic invertebrates.

Barrow Island lies in the Fortescue Botanical District, a subdivision of the Eremaean Botanical Province as defined by Beard (1980). The flora, while typical of the arid Pilbara Region, has floral affinities with the Cape Range area on the mainland (Trudgen 1989; Astron 2011).

Barrow Island is recognised as an important refuge for native mammal species and subspecies that are endemic, or have either declined in numbers or become extinct on the mainland. Five are listed by the Western Australian Department of Environment and Conservation as rare or likely to become extinct: Burrowing Bettong or Boodie, Barrow Island Golden Bandicoot, Spectacled Harewallaby, Barrow Island Euro, Black-flanked Rockwallaby. Most of the mammals are widespread and abundant on Barrow Island (Chevron Australia 2005, Moro and MacAulay 2010a).

Barrow Island is designated as an Important Bird Area by BirdLife International because it offers important habitat for summer and winter migratory shorebirds (Bamford et al. 2011). Shorebirds abundances are highest on the coast in the south-east and south of Barrow Island, although abundance does vary with season (Bamford et al. 2011). Fifty-one species of terrestrial avifauna have been recorded; however, about 16 of these species are residents or regular migrants to the island (Moro and MacAulay 2010b). Most species are vagrants from the adjacent mainland. The common landbirds on Barrow Island are the Spinifexbird (Eremiornis carteri), White-winged Fairy wren (an endemic subspecies, Malurus leucopterus edourdii), Singing Honeyeater (Lichenostomus virescens), Whitebreasted Wood Swallow (Artamus leucorhynchus) and Welcome Swallow (Hirundo neoxena).

The terrestrial herpetofauna includes a diversity of taxa occupying various niches, from small sanddwelling skinks, dragons, and snakes up to the large varanid lizards. Barrow Island is home to 43 species of reptiles comprising dragons (3 species), legless lizards (5), geckoes (5), skinks (19), blind snakes (3), monitors (3), and snakes (5). One species of frog occurs on the island (Moro and MacAulay 2010c). Most species, and their habitats, are widely distributed across Barrow Island.

Four species of marine turtle have been reported to nest on Barrow Island: Hawksbill Turtle Eretmochelys imbricata, Loggerhead Turtle Caretta caretta, Flatback Turtle Natator depressus, Green Turtle Chelonia mydas. However, the Flatback Turtle and Green Turtle are the most abundant. Green Turtles nest on the majority of sandy beaches especially along the west coast of Barrow Island, while non-nesting turtles forage on the algae- covered rocky platforms throughout the year. Flatback Turtles favour the mid-east coast beaches for nesting.

Subterranean fauna (troglofauna and stygofauna) from Barrow Island are important from a biodiversity perspective due to their endemicity at high taxonomic levels. Surveys have indicated that stygofauna occur in groundwater habitats across the island due to a water lens that hydrogeological models suggest is not disrupted (Groundwater Consulting Services 2005; Biota Environmental Services 2007; Golder Associates 2011). In addition to stygofauna, areas of karst also provide habitat for troglobitic fauna (terrestrial subterranean fauna).

Invertebrates are an important component of the faunal biodiversity of Barrow Island, and are the most biodiverse of the groups on the island. The invertebrates, including short range endemic species with restricted habitat distributions, were until recently poorly documented (Callan et al. 2011; Majer et al. 2013).

\section{DISTURBED ENVIRONMENT}

Barrow Island is not an undisturbed environment. A description of this island would therefore be remiss without acknowledging the infrastructure which exists from a long-standing oil industry and, more recently, the developing gas industry that forms part of the landscape. Importantly, the early infrastructure that was decommissioned and later rehabilitated has offered a variety of semi-disturbed mosaics of vegetation across the landscape that affords various habitats to support early colonising species.

The natural environment on the island functions amidst a network of managed roads, pipelines, storage tanks, accommodation, over 900 cleared well pads (with approximately 460 producing wells), water injection wells, an offshore port, airstrip with facilities, and other infrastructure to support an onshore producing oilfield. The majority of infrastructure occurs in the mid to southern portions of the island above the Windalia (oil) reservoir some 600-700 $\mathrm{m}$ deep. Less infrastructure is present in the northern part of the island. More recently and under a State Agreement, 300 ha of 23, 400 ha of land has been cleared to support the Gorgon Gas Development to develop a gas processing plant on the island. This infrastructure is carefully managed to retain the ecological function of Barrow Island.

Chevron Australia's key environmental objective is to protect the biodiversity values of Barrow Island while maintaining its resource operations. Protection of the island's conservation values has focused on four areas: quarantine management to ensure non-indigenous species do not enter the 
island; workforce education on the environmental values of Barrow Island; progressive rehabilitation to reinstate disused production areas; and careful planning of infrastructure to maintain the island's ecosystem functions and processes. Over the past 50 years, this environmental ethos has enabled petroleum activities to successfully coexist with Barrow Island's flora and fauna. No species are known to have gone extinct since oilfield development commenced, no non-indigenous vertebrates have established, and weeds are managed to contain their spread.

Today, a carefully managed environmental monitoring program, coupled with an extensive quarantine surveillance program, has improved knowledge of the biota that exists on Barrow Island, and provides insight into the dynamics of its ecosystem values across time. With the consistent human settlement on the island since oil exploration commenced in the 1960s, maintaining partnerships over time between the company operators including the island workforce, together with the managing government departments, have ensured the ecosystem values have not been compromised akin to those on the adjacent mainland. The management of oilfield operations on Barrow Island is widely recognised as an industry benchmark for the successful coexistence of petroleum development and biodiversity protection.

\section{REFERENCES}

Astron (2011). Barrow Island Flora and Vegetation Review. Chevron Australia, Perth, Western Australia.

Bamford, M., Moro, D. and Craig, M. (2011). Barrow Island as an important bird area for migratory waders in the east Asian-Australasian flyway. Stilt 60: 46-55.

Beard, J.S. 1980. A New Phytogeographic Map of Western Australia. Western Australian Herbarium Notes 3: 37-58.

Biota Environmental Sciences (2007). Barrow Island Gorgon Gas Development: Summary of 20042006 Subterranean Fauna Surveys. Report prepared for Chevron Australia, Perth, Western Australia.

Callan, S.K., Majer, J.D., Edwards, K. and Moro, D. (2011). Documenting the terrestrial invertebrate fauna of Barrow Island, Western Australia. Australian Journal of Entomology 50: 323-343.

Chevron Australia (2005). Draft Gorgon Environmental Impact Statement/Environmental Review and Management Programme for the Proposed Gorgon Development. Chevron Australia, Perth, Western Australia.

Chevron Australia (2006). Final Environmental Impact Statement/Environmental Review and Management Programme for the Gorgon Gas Development. Chevron Australia, Perth, Western Australia.

Commonwealth Government of Australia (2007). Approval - Gorgon Gas Development (EPBC Reference: 2003/1294), 3 October 2007. Canberra, Australian Capital Territory, Australia.
Commonwealth Government of Australia (2009). Approval - Gorgon Gas Development (EPBC Reference: 2008/4178), 26 August 2009. Canberra, Australian Capital Territory, Australia.

Department of Conservation and Environment (2006). Management Plan for the Montebello/Barrow Islands Marine Conservation Reserves, 2007-2017. Management Plan No. 55. Department of Conservation and Environment, Perth, Western Australia.

Environment Australia (2000). Revision of the Interim Biogeographic Regionalisation for Australia (IBRA) and Development of Version 5.1. Environment Australia, Canberra, Australian Capital Territories.

Groundwater Consulting Services (2005). Barrow Island Hydrogeology and Groundwater Resource Assessment, Pilbara, Western Australia. Report prepared for Chevron Australia, Perth, Western Australia.

Golder Associates (2011). Update Of The Gorgon Gas Treatment Plant Site Conceptual Model, Barrow Island. Unpublished Letter to Chevron Australia, Perth, Western Australia.

Government of Western Australia (2007). Statement that a Proposal may be Implemented - Gorgon Gas Development: Barrow Island Nature Reserve (Ministerial Statement No. 748), 6 September 2007. Perth, Western Australia.

Government of Western Australia (2009). Statement that a Proposal may be Implemented - Gorgon Gas Development Revised and Expanded Proposal: Barrow Island Nature Reserve (Ministerial Statement No. 800), 10 August 2009. Perth, Western Australia.

Hook, F., McDonald, E., Paterson, A., Souter, C. And Veitch, B. (2005). Cultural heritage assessment and management plan-proposed Gorgon Development, Pilbara, North Western Australia. In Draft Gorgon Environmental Impact Statement/Environmental Review and Management Programme for the Proposed Gorgon Development. Appendix E1. Chevron Australia, Perth, Australia.

Horsburgh, L. (2008). Of Oil and Men: My Barrow Island Story. pp299. Self published.

Majer, J.D., Callan, S.K., Edwards, K., Gunawardene, N.R. and Taylor, C.K. (2013). Baseline survey of the terrestrial invertebrate fauna. Records of the Western Australian Museum, Supplement 83: 13-112.

Moro, D. And MacAulay, I. (2010a). A Guide to the Mammals of Barrow Island. Chevron Australia Pty Ltd, Perth, Western Australia.

Moro, D. And MacAulay, I. (2010b). A Guide to the Birds of Barrow Island. Chevron Australia Pty Ltd, Perth, Western Australia.

Moro, D. And MacAulay, I. (2010c). A Guide to the Reptiles and Amphibians of Barrow Island. Chevron Australia Pty Ltd, Perth, Western Australia.

Playford, P. E. (1997). Geology and hydrogeology of Rottnest Island, Western Australia. Developments in Sedimentology 54: 783-810.

Smith, D. N. (1962). Barrow Island Geological Survey, Carnarvon Basin. West Australian Petroleum Report No. 313. Perth, Western Australia.

Thackway, R. and Cresswell, I.D. (eds) (1995). An Interim Biogeographic Regionalisation for Australia: 
a framework for establishing the national system of reserves, Version 4.0. Australian Nature Conservation Agency Canberra, Australian Capital Territories.

Trudgen, M.E. (1989). A Report on the Progress of the Regeneration of Vegetation on Areas Disturbed During Oil Production on Barrow Island. West Australian Petroleum Pty Limited (WAPET), Perth, Western Australia.

Veth, P. (1994). The Aboriginal occupation of the
Montebello Islands, north-west Australia. Australian Aboriginal Studies 2: 39-50.

Worley (2003). Gorgon Metocean Modelling. Report on Nearshore Wave, Circulation and Dispersion Modelling. Report prepared for ChevronTexaco Australia, Perth, Western Australia.

MANUSCRIPT RECEIVED 13 DECEMBER 2012; ACCEPTED 20 MARCH 2013. 